Document downloaded from:

http://hdl.handle.net/10251/62733

This paper must be cited as:

Josep Domenech; Martinez Gomez, VD.; Mas Verdú, F. (2014). Location and Adoption of ICT Innovations in the agri-food industry. Applied Economics Letters. 21(6):421-424. doi:10.1080/13504851.2013.864032.

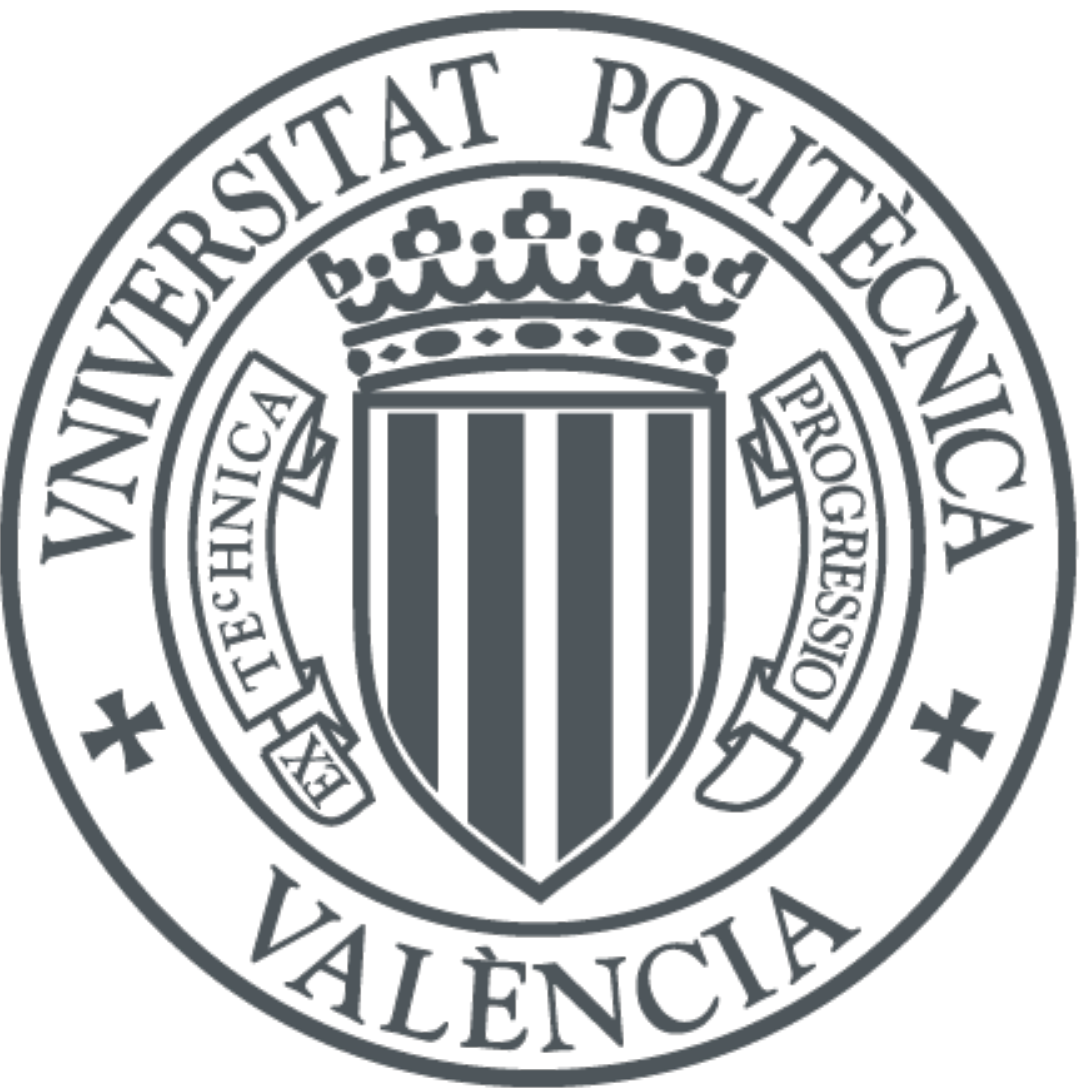

The final publication is available at

http://dx.doi.org/10.1080/13504851.2013.864032

Copyright Taylor \& Francis (Routledge): SSH Titles

Additional Information

This is an author's accepted manuscript of an article published in:

"Applied Economics Letters"; Volume 21, Issue 6, 2014; copyright Taylor \& Francis; available online at: http://dx.doi.org/10.1080/13504851.2013.864032 


\title{
Location and Adoption of ICT Innovations in the Agri-food Industry
}

\author{
Josep Domenech $^{1}$, Victor Martinez-Gomez ${ }^{\prime}$, and Francisco Mas-Verdú ${ }^{1}$ \\ ${ }^{1}$ Department of Economics and Social Sciences, \\ UniversitatPolitècnica de València, Valencia, Spain \\ Email:jdomenech@upvnet.upv.es, vicmargo@esp.upv.es,fmas@upvnet.upv.es
}

\begin{abstract}
This article identifies the web technologies adoption pattern of agri-food industries considering a set of characteristics which include location, economic performance and previous history of adopting innovations. Our main results highlight that, together with certain firm characteristics, rural locations act as an accelerator for the adoption of web technology, compared to the slower adoption rate in urban areas.
\end{abstract}

\section{Introduction}

The development of Information and Communication Technologies (ICTs) has greatly reduced the cost of processing and transmitting information, thus reducing the importance of distance and business location. The rational expectations theory points out that businesses will decide to adopt ICTs when they expect positive returns from adopting them (Au and Kauffman, 2003). As long as the distance from densely populated areas is one of the disadvantages of rural locations, firms in these areas can be expected to receive higher returns from adopting ICTs, i.e. they can act as a 
potential boost for firms in rural areas. However, from the point of view of the territorial innovation models, adopting such innovations could be faster in urban environments, since rural areas may lack the appropriate infrastructure and skilled personnel (Moulaert and Sekia, 2003).

The agri-food industry is traditionally located in rural areas and is therefore an interesting case study as regards ICT adoption. The usual view on its innovative pattern indicates that it has low innovative intensity compared to other sectors (Capitanio et al., 2009). However, recent evidence indicates that its innovation intensity may be greater than traditionally considered (Garcia et al., 2012).

Internet has had uneven acceptance among agri-food companies across locations. Figure 1 shows the year in which rural and urban firms in our sample adopted a corporate website. It can be seen that since 2000 Internet has been adopted by a substantially higher fraction of firms in rural areas than in urban locations. This suggests that location matters when incorporating ICTs. In this vein, this paper explores the relationship between location and ICT adoption by the Spanish agri-food industry. 


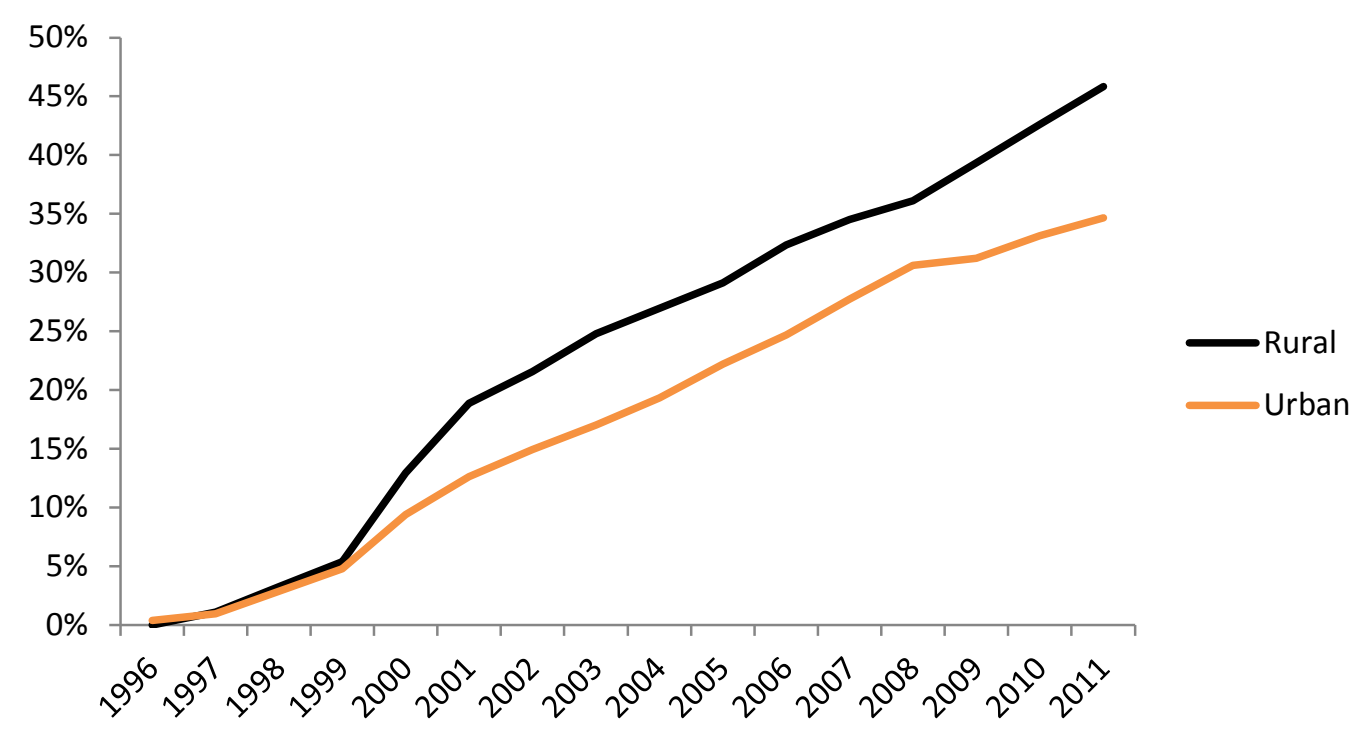

Figure 1.Yearly website adoption by rural and urban agri-food firms.

\section{Theretical Framework}

There are two broad categories of variables that influence ICT adoption. The first includes variables related to the characteristics of the firm and the second includes the characteristics of the firm's environment.

The first firm characteristic is size. The effect of size on innovation is ambiguous. On the one hand, the availability of resources $(\mathrm{R} \& \mathrm{D}$, financial resources and organizational character) is associated with larger firms (Mowery et al., 1996). This factor confirms the greater ability of large companies to innovate. On the other hand, some authors (Liao et al., 2003) have found greater agility and flexibility of smaller companies in adopting innovations because of their less complex bureaucratic structure. 
The existence of a positive relationship between innovation and export behavior has also been pointed out. As a result of the higher levels of efficiency required for competing in international markets, exporting firms tend to be more innovation-intensive than non-exporters (Bernard et al., 2005). As international markets are subject to greater competitive pressure, innovation is a key variable for exports. Both phenomena are often presented in the form of a circular relationship (Kafouros et al 2008).

The level of training and competence of the workforce are determinants for the adoption and use of innovations. As Giunta and Trivieri (2007) point out, the "better" the human capital, the higher the adoption of ICTs.

Among the environmental factors, location may bolster or undermine the innovation process. This question is especially relevant in the agri-food industry because it is often closely linked to the territory. In a recent study, Fearne et al. (2013) found that rural businesses were just as innovative as their urban counterparts.

Concerning the relationship between location and ICT adoption, early studies proposed the existence of a vicious circle: the lack of communication infrastructure in rural environments reduces the demand for communication services, which further constrains future investments in infrastructure (Premkumar and Roberts, 1999). As the gap in infrastructures in rural areas has been filled in the developed countries, the 
widespread availability of ICTs has reduced the influence of location, making geographic distance less relevant. Forman et al. (2005) suggest that adopting ICT is a way to overcome the relative isolation experienced by firms located in rural areas. They also found evidence that Internet is more widely used in rural than in urban areas. Galliano and Roux (2008) did not find such strong evidence in French industrial firms. Indeed, according to their results, the determinants of adoption are generally similar in both urban and rural firms.

Some authors also find a relationship between the degree of competition and the level of innovation, with contradictory empirical evidence (Tingvall and Poldahl, 2006). This is in line with the work of Aghion et al. (2005), who modeled an inverted-U relationship between innovation and competition.

\section{Methodology and data}

The sample for this study consisted of 740 companies in the agri-food industry (NACE Rev. 2 Codes 10 and 11) located in the Regions of Valencia and Navarra in Spain. The sample was randomly retrieved from the SABI database. ${ }^{1}$ The economic variables collected from SABI included the following information from the 2011 records:

\footnotetext{
${ }^{1}$ SABI: Sistema de Análisis de Balances Ibéricos. It is published by Bureau van Djick.
} 
- SIZE: Continuous variable which was measured by the logarithm of the number of the firm's employees.

- Average remuneration (WAGE): Continuous variable measured as average wage per employee, considered as an approximation to employees' skills.

- Export orientation (EXPORT): Dichotomous variable: 1 if the firm is an exporter and 0 otherwise.

This set of variables was supplemented by information from other sources on location characteristics, website adoption and level of competition in the subsector:

- Urban or rural location (RURAL): A dummy variable that takes the value 1 when the firm's head office is in a rural area and 0 in an urban area. A local unit is considered as rural when its population density is below 150 inhabitants per square kilometer (OECD, 1994).

- Website adoption (WEBSITE): This is a dummy variable that takes the value 1 if the company had a corporate website and 0 if otherwise. This variable was determined by querying a search engine with the business name or its VAT number, as firms are obliged by Spanish regulations to include this information in their website.

- CONCENTRATION: the level of competition within a given sector may be measured through its concentration level. We adapted the computations of the 
Herfindahl Index by Toribio et al. (2012) for sub-sectors of the Spanish agri-food industry. The firms in our sample are classified in three levels of concentration.

With these variables, the following probit model enabled us to study the influence of each one on the adoption of ICT innovations:

$$
\text { Adoption }=\Phi(\text { Firm characteristics, firm environment })
$$

where ICT adoption is measured by the WEBSITE variable. Firm characteristics include its size, average remuneration and export orientation, while the environment factor includes location and the level of competition in the subsector.

Table 1 shows the sample's main descriptive statistics. It is dominated by non-exporting firms located in urban areas, and only $40 \%$ of the firms have an operating website.

[Insert Table 1 Here]

\section{Results}

Table 2 shows the proposed model's estimation results. The main variables affecting the adoption of ICT innovations are firm size and its export orientation, both in the expected direction. That is, larger companies are more likely to adopt ICTs, as well as those oriented towards international markets. 
The environmental variables have a lower impact than those related to intrinsic firm characteristics. Only location affects the Internet adoption decision of firms in the agri-food sector. The coefficients in Table 2 indicate that, for the average firm, the probability of a rural firm adopting Internet is 9.1 percentage points higher than a similar firm in an urban area, which confirms the trend shown in Figure 1.

\section{Conclusions}

The adoption of ICT technologies is a key innovation for firms, both in their internal organizational operations and in their relationship with external actors. This paper describes the empirical analysis of the determinants of Internet adoption by firms in the Spanish agri-food sector. Our results show that the firm's characteristics are the main determinants of whether or not it adopts ICT innovations, the main influences being business size and export orientation.

As regards the influence of firm location, our analysis found that businesses in rural areas are more likely to adopt ICT innovations. These findings suggest that the benefits of adopting ICT exceed the costs related to the scarcity of infrastructure and skilled personnel and highlight the role of rural locations as accelerators of the adoption of ICT technologies.

\section{Acknowledgements}


The authors are grateful for the support received from the Universitat Politècnica de València, (PAID-06-12) and the Spanish Ministry of Science and Innovation (TIN2009-08201).

\section{References}

Aghion, P., Bloom, N., Blundell, R., Griffith, R. and Howitt, P. (2005): Competition and innovation: an inverted-U relationship, Quarterly Journal of Economics, pp. 701-728

Au, Y. A., and Kauffman R. J. (2003). What do you know? Rational expectations in information technology adoption and investment. Journal of Management Information Systems. 20, 49-76.

Bernard, A. B., Bradford, J., and Schott, K.P. (2005).Firms in International Trade. Journal of Economic Perspectives, 21 (3):105-130.

Capitanio, F., Coppola, A. and Pascucci, S. (2009), "Indications for drivers of innovation in the food sector”. British Food Journal, 111(8):820-838.

Fearne, A., García, J.M., López-García, T., and Sanchez, M. (2013). Innovative firms and the urban/rural divide.Management Decision, 51(6):1293-1310.

Forman C., Goldfarb A., and Greenstein S. (2005) How did location affect adoption of the commercial Internet? Global village vs. urban leadership. J Urban Econ 58(3):389-420

Galliano, D. and Roux, P. (2008). Organisational motives and spatial effects in Internet adoption and intensity of use: evidence from French industrial firms. Annals of Regional Science, 42:425-448.

García, J.M., Alba, M., and López-García, T. (2012) Innovation and sectoral linkages in the agri-food system in the Valencian Community. Spanish Journal of Agricultural Research 10(1):18-28.

Giunta, A. and Trivieri, F. (2007). Understanding the determinants of information technology adoption: evidence from Italian manufacturing firms. Applied Economics, 39(10): 1325-1334.

Kafouros M.I., P.J. Buckley, J.A. Sharp, C. Wang (2008). 'The role of internationalization in explaining innovation performance.'Technovation, 28(1-2):63-74.

Liao, J., Welsch, H., and Stoica, M. (2003).Organizational Absorptive Capacity and Responsiveness: An Empirical Investigation of Growth-Oriented SMEs'. Entrepreneurship: Theory and Practice, 28 (1):63-86.

Moulaert, F., and Sekia F. (2003). Territorial Innovation Models: A Critical Survey. Regional Studies. 37(3):289-302.

Mowery, D.C., Oxley J., and Silverman, B.S. (1996). Strategic alliances and interfirm knowledge 
transfer. Strategic Management Journal, 17:77-91.

OECD (1994). Creating rural indicators for shaping territorial policy. OECD Publications, Paris, France.

Premkumar, G. and Roberts, M. (1999). Adoption of new information technologies in rural small businesses. The international Journal of Management Science, 27:467-484.

Tingvall, P.G. and Poldahl, A. (2006): Is there an inverted Ushaped relation between competition and R\&D?,Economics of Innovation and New Technology, 15(2):101-118.

Toribio, J., Díaz-Giménez, J., Campos, and R., Gómez, G. (2012). La cadena agroalimentaria en España. IESE Business School. 
Table 1. Descriptive statistics and correlation matrix

\begin{tabular}{lrrrrrrr}
\hline & \multicolumn{1}{c}{ Mean } & \multicolumn{1}{c}{ S.D. } & ( 1) & ( 2) & (3) & (4) & ( 5) \\
\hline 1. Size & 2.184 & 1.266 & & & & & \\
2. Average remuneration & 25.754 & 12.435 & .073 & & & & \\
3. Exporter & .203 & .402 & .456 & .233 & & & \\
4. Rural & .262 & .440 & .007 & .014 & .066 & & \\
5. Concentration & .523 & .762 & .109 & .079 & .139 & .063 & \\
6. Website & .400 & .490 & .433 & .134 & .384 & .084 & .131 \\
\hline
\end{tabular}

Table 2. Determinants of adoption of Web technologies

\begin{tabular}{lccc}
\hline Variable & $\beta$ & $\begin{array}{l}\text { Std. } \\
\text { Error }\end{array}$ & p-value \\
\hline Size & 0.681 & 0.085 & 0.000 \\
Average & 0.012 & 0.007 & 0.115 \\
remuneration & & & \\
Exporter & 1.207 & 0.244 & 0.000 \\
Rural & 0.373 & 0.195 & 0.056 \\
Concentration & 0.184 & 0.112 & 0.102 \\
(Constant) & -2.666 & 0.288 & 0.000 \\
\hline N & & 740 & \\
Pseudo- $R^{2}$ & & 0.313 & \\
Hosmer-Lemeshow & & 0.936 & \\
\hline
\end{tabular}

